\title{
PENGARUH PEMBELAJARAN KOOPERATIF TERHADAP KECEMASAN MATEMATIKA
}

\author{
Risma Nurul Auliya \\ Program Studi Informatika, Universitas Indraprasta PGRI \\ Email: rismauliya@gmail.com
}

\begin{abstract}
Abstrak
Penelitian ini bertujuan untuk mengkaji penerapan model pembelajaran kooperatif untuk megatasi kecemasan matematika siswa SMP. Desain penelitian yang digunakan adalah kuasi eksperimen. Populasinya, yaitu seluruh siswa SMP kelas VIII di salah satu SMP Negeri Jakarta Selatan. Adapun, sampelnya terdiri dari 32 siswa kelas kooperatif (kelompok eksperimen) dan 34 siswa kelas konvensional (kelompok kontrol) yang dipilih menggunakan teknik purposive sampling. Masalah yang diteliti, yaitu menguji perbedaan kecemasan matematika siswa pada kelas kooperatif dan kelas konvensional. Instrument penelitian yang digunakan adalah kuesioner kecemasan matematika siswa. Analisis kuantitatif menggunakan uji statistik Mann-Whitney, sedangkan analisis kualitatif dilakukan secara deskriptif. Hasil penelitian menunjukkan bahwa kecemasan matematika kelas kooperatif lebih rendah daripada kelas konvensional.
\end{abstract}

Kata kunci: pembelajaran Kooperatif, kecemasan matematika.

\begin{abstract}
The aim of this research is intended to examine the effect of cooperative learning model towards students' mathematics anxiety. The research utilized a quasi experimental design. The population in this research was grade-8 students of a junior high school in South Jakarta. The sample comprised 32 students in cooperative group (as the experiment group) and 34 students in conventional group (as the control group). The instrument comprised Mathematics Anxiety Questionnaire (MAQ). The research problem was to examine the difference of mathematics anxiety between students in cooperative group and conventional one. The quantitative analysis used Mann-Whitney U test, while qualitative analysis used descriptive one. The result showed that students' mathematics anxiety in cooperative group was lower than conventional one.
\end{abstract}

Key words: cooperative learning, mathematics anxiety.

\section{PENDAHULUAN}

Matematika adalah suatu pelajaran yang universal dan telah menjadi bagian penting dalam kehidupan sehari-hari, sehingga seorang individu yang juga merupakan bagian dari suatu masyarakat, sebaiknya memiliki pengetahuan mengenai konsep dasar matematika [1]. Seseorang yang mempelajari matematika terbiasa untuk berpikir secara sistematis, ilmiah, kritis, dan menggunakan logika, sehingga dapat memiliki daya kreativitas yang baik. Selain itu, mempelajari matematika memudahkan seseorang dalam memahami berbagai informasi serta menyelesaikan masalah yang disajikan dalam bahasa dan model matematika. Menyadari pentingnya belajar matematika, maka pemerintah menjadikan matematika sebagai salah satu salah satu mata pelajaran wajib bagi siswa pada jenjang pendidikan dasar dan menengah, hal ini tercantum dalam Undang-undang RI No. 20 Tahun 2003 tentang Sisdiknas (Sistem Pendidikan Nasional) Pasal 37.

Pentingnya seseorang mempelajari matematika tidak didukung oleh anggapan siswa mengenai matematika, yaitu matematika adalah pelajaran yang sulit [2], karena konsep-konsep dalam matematika bersifat abstrak serta banyaknya rumus yang harus diingat [3]. Yusof dan Tall berpendapat bahwa sikap negatif terhadap matematika biasanya muncul ketika siswa mengalami kesulitan dalam menyelesaikan soal atau ketika ujian, jika kondisi ini 
terjadi secara berulang-ulang maka sikap negatif siswa akan berubah menjadi kecemasan matematika [4].

Kecemasan matematika merupakan sejenis penyakit, yang mengacu pada reaksi suasana hati yang tidak sehat, yang terjadi ketika seseorang menghadapi persoalan matematika. yang menunjukkan mereka panik dan kehilangan akal, depresi, pasrah, gelisah, takut, dan disertai dengan beberapa reaksi psikologi, seperti berkeringat pada wajahnya, mengepalkan tangan, sakit, muntah, bibir kering, dan pucat [5]. Sparks berpendapat bahwa kecemasan matematika dapat menyebabkan siswa menghindar dari pelajaran dan segala sesuatu yang berhubungan dengan matematika [6].

Beberapa hasil penelitian menyatakan bahwa kecemasan matematika merupakan salah satu faktor yang memiliki hubungan negatif dengan prestasi belajar siswa. Clute dan Hembree menemukan bahwa siswa yang memiliki tingkat kecemasan matematika yang tinggi memiliki prestasi belajar matematika yang rendah [7]. Hasil penelitian [8] juga menunjukkan bahwa kecemasan matematika berkorelasi negatif dengan kinerja matematika.

Miller dan Mitchell berpendapat bahwa untuk mengurangi kecemasan matematika dan meningkatkan prestasi siswa, guru seharusnya menciptakan lingkungan pembelajaran yang positif, yang bebas dari ketegangan dan memungkinkan timbulnya perasaan malu atau terhina [9], dan salah satu model pembelajaran yang dapat digunakan adalah model pembelajaran kooperatif. Hal ini sejalan dengan hasil penelitian yang dilakukan oleh Millis, yang menemukan bahwa pembelajaran kooperatif dapat digunakan untuk mengurangi kecemasan matematika pada siswa [10].
Pembelajaran kooperatif merupakan suatu pembelajaran yang membagi siswa ke dalam beberapa kelompok kecil, kelompok kecil siswa tersebut bekerja sebagai sebuah tim untuk menyelesaikan suatu masalah, menyelesaikan suatu tugas, atau mengerjakan sesuatu untuk mencapai tujuan bersama [11]. Dalam pembelajaran kooperatif, siswa memiliki kesempatan untuk mempelajari konsep matematika yang sulit dengan bertanya pada teman sebayanya, sehingga mereka merasa lebih percaya diri pada kemampuan mereka dalam belajar matematika, serta dapat mengurangi kecemasan matematika.

Tujuan dari penelitian ini adalah untuk mengkaji perbedaan tingkat kecemasan matematika antara siswa yang memperoleh pembelajaran kooperatif dan siswa yang memperoleh pembelajaran konvensional. Dengan manfaat penelitiannya adalah untuk mengetahui apakah terdapat perbedaan pada tingkat kecemasan matematika antara siswa yang mendapatkan pembelajaran kooperatif dan siswa yang mendapatkan pembelajaran konvensional. Adapun, hipotesis penelitiannya adalah siswa yang memperoleh pembelajaran kooperatif memiliki kecemasan matematika yang lebih rendah daripada siswa yang memperoleh pembelajaran konvensional.

\section{METODE}

Penelitian ini menggunakan Nonequivalent Control Group Design, yang merupakan bentuk desain dari Quasi Eksperimental, di mana subjek penelitian tidak dikelompokkan secara acak. Pola rancangan digambarkan sebagai berikut:

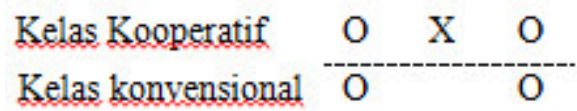


dengan,

$$
\begin{array}{lll}
\mathrm{O} & : & \text { pretes, postes pada kelas } \\
& \text { kooperatif dan konvensional } \\
\mathrm{X} & : & \text { perlakuan model } \\
& \text { pembelajaran kooperatif } \\
------= & \text { subjek tidak dikelompokkan } \\
& \text { secara acak }
\end{array}
$$

Populasi untuk penelitian ini adalah seluruh siswa kelas VIII di salah satu SMP di Jakarta Selatan, dan sampel penelitiannya adalah dua kelas pada tingkat VIII. Penentuan sampel dilakukan dengan menggunakan teknik purposive sampling. Dua kelas akan dipilih sebagai sampel penelitian dari lima buah kelas VIII yang tersedia, yaitu kelas VIII-A sebagai kelas kooperatif (eksperimen) dan kelas VIII-C sebagai kelas konvensional (kontrol). Pemilihan kedua kelas tersebut didasarkan dari nilai rerata UTS matematika.

Instrumen untuk mengukur kecemasan matematika yang digunakan dalam penelitian ini adalah skala kecemasan matematika yang diadaptasi dari kuesioner kecemasan matematika [12] dan terdiri dari 44 item pernyataan. Kuesioner ini terdiri atas dua bagian, yaitu kecemasan matematika ketika belajar matematika secara berkelompok dan ketika mengerjakan tes matematika. Berdasarkan hasil adaptasi dari kuesioner tersebut, diambil 28 pernyataan yang meliputi aspek somatik, kognitif, sikap, dan pemahaman matematis. Kecemasan matematika ketika belajar matematika secara berkelompok terdiri dari 12 pernyataan dan kecemasan matematika ketika mengerjakan tes matematika terdiri dari 16 pernyataan. Selanjutnya, siswa diminta untuk menjawab kuesioner tersebut dengan memberi tanda centang $(\sqrt{ })$ pada hanya satu pilihan jawaban yang telah tersedia, yang terdiri dari empat pilihan, yaitu Sangat Setuju (SS), Setuju (S), Tidak
Setuju (TS), dan Sangat Tidak Setuju (STS).

Pemberian skor setiap pilihan dari pernyataan skala kecemasan matematika ditentukan dengan metode summated ratings, menggunakan cara deviasi normal. Selanjutnya, analisis data berupa skor skala kecemasan matematika siswa dianalisa secara kuantitatif dengan menggunakan uji statistik non-parametrik Mann-Whitney, sedangkan analisis data kualitatif dianalisis secara deskriptif.

\section{HASIL DAN PEMBAHASAN \\ Statistik Deskriptif}

Statistik deskriptif skor kecemasan matematika siswa pada kelas kooperatif dan kelas konvensional ditunjukkan pada Tabel 1.

Tabel 1. Statistik Deskriptif Skor Kecemasan Matematika

\begin{tabular}{llllcll}
\hline & $\mathbf{N}$ & $\mathbf{X}_{\min }$ & $\mathbf{X}_{\text {maks }}$ & $\overline{\boldsymbol{x}}$ & $\mathbf{S D}$ & $\mathbf{\%}$ \\
\hline $\begin{array}{l}\text { Koope- } \\
\text { ratif }\end{array}$ & 32 & 15 & 39 & 27,09 & 5,330 & 64,50 \\
$\begin{array}{l}\text { Konven- } \\
\text { sional }\end{array}$ & 34 & 16 & 36 & 29,97 & 5,266 & 71,36 \\
Skor maksimum ideal = 42 & & & \\
\hline
\end{tabular}

Berdasarkan Tabel 1, terlihat bahwa skor minimum kecemasan matematika siswa kelas kooperatif lebih rendah daripada kelas konvensional, sedangkan skor maksimum siswa kelas kooperatif lebih tinggi daripada kelas konvensional. Walaupun begitu, rerata skor kecemasan matematika siswa kelas kooperatif lebih rendah daripada kelas konvensional, yaitu sebesar 27,09 untuk kelas kooperatif dan rerata sebesar 29,97 untuk kelas konvensional.

Deviasi standar skor kecemasan matematika siswa kelas kooperatif lebih tinggi daripada kelas konvensional, hal ini berarti siswa kelas kooperatif memiliki skor kecemasan matematika yang lebih bervariasi daripada kelas konvensional. 
Rerata skor kelas kooperatif lebih rendah 2,88 atau $6,86 \%$ daripada kelas konvensional, yang artinya kecemasan matematika siswa pada kelas kooperatif lebih rendah dibandingkan dengan siswa kelas konvensional, sehingga dapat dikatakan bahwa pembelajaran dengan model pembelajaran kooperatif memberikan kontribusi yang baik dalam mengurangi kecemasan matematika siswa dibandingkan dengan pembelajaran konvensional.

\section{Analisis Skor Kecemasan Matematika}

Analisis skor kecemasan matematika siswa menggunakan uji perbedaan dua rerata skor kecemasan matematika, yang bertujuan untuk mengetahui apakah terdapat perbedaan skor kecemasan matematika siswa yang mendapatkan pembelajaran kooperatif dan siswa yang mendapatkan pembelajaran konvensional setelah pembelajaran dilakukan. Sebelum data dianalisis, terlebih dahulu dilakukan uji asumsi statistik, yaitu uji normalitas dan uji homogenitas.

\section{Uji Normalitas}

Hasil perhitungan uji normalitas skor kecemasan matematika disajikan pada Tabel 2.

Tabel 2. Hasil Uji Normalitas Skor Kecemasan Matematika

\begin{tabular}{lll}
\hline Kelas & $\begin{array}{l}\text { Shapiro- } \\
\text { Wilk } \\
\text { (Sig.) }\end{array}$ & Kesimpulan \\
\hline Kooperatif & 0,420 & $\begin{array}{l}\text { data berdistribusi } \\
\text { normal } \\
\text { data tidak } \\
\text { berdistribusi } \\
\text { normal }\end{array}$ \\
\hline
\end{tabular}

Tabel 2 menunjukkan bahwa skor kecemasan matematika siswa kelas kooperatif memiliki nilai Sig. $>\alpha$, dengan $\alpha=0,05$ sehingga $\mathrm{H}_{0}$ diterima. Hal ini menunjukkan bahwa data skor kecemasan matematika siswa kelas kooperatif berdistribusi normal. Sementara itu, skor kecemasan matematika siswa kelas konvensional memiliki nilai Sig. $<\alpha$, sehingga $\mathrm{H}_{0}$ ditolak. Hal ini menunjukkan bahwa data skor kecemasan matematika siswa kelas konvensional tidak berdistribusi normal.

\section{Uji Perbedaan Dua Rerata Skor}

Kecemasan Matematika

Setelah diketahui bahwa hanya data skor kecemasan matematika kelas kooperatif yang berdistribusi normal, sedangkan kelas konvensional tidak berdistribusi normal, uji perbedaan dua rerata skor kecemasan matematika dilakukan menggunakan uji statistik non-parametrik Mann-Whitney. Hasil perhitungan dapat dilihat pada Tabel 3.

$\begin{gathered}\text { Tabel 3. Hasil Uji Mann-Whitney Skor } \\
\text { Kecemasan Matematika }\end{gathered}$
\begin{tabular}{lll}
\hline $\mathrm{Z}$ & Sig. (1-tailed) & Keterangan \\
\hline $\mathbf{- 2 , 2 7 9}$ & 0,023 & $\mathrm{H}_{0}$ ditolak \\
\hline
\end{tabular}

Hasil uji statistik non-parametrik MannWhitney pada Tabel 3 menunjukkan nilai $\left|Z_{\text {hitung }}\right|$, yaitu 2,279. $\left|Z_{\text {hitung }}\right|>\left|Z_{\text {kritis }}\right|$, dengan $\left|Z_{\text {kritis }}\right|=1,65$ atau nilai Sig. (1tailed), yaitu $0,023<\alpha$ sehingga $\mathrm{H}_{0}$ ditolak. Karena nilai $\left|Z_{\text {hitung }}\right|>\left|Z_{\text {kritis }}\right|$ atau Sig. $<\alpha$, serta rerata skor kecemasan matematika kelas kooperatif lebih redah dari kelas konvensional (lihat Tabel 1), sehingga dapat disimpulkan bahwa kecemasan matematika siswa yang memperoleh pembelajaran kooperatif lebih rendah daripada siswa yang mendapatkan pembelajaran konvensional.

Hasil penelitian yang diperoleh menunjukkan bahwa pembelajaran kooperatif terbukti dapat mengatasi kecemasan matematika. Hasil ini serupa dengan hasil dari penelitian yang dilakukan oleh [10], karena pada pembelajaran kooperatif, proses yang terjadi ketika pembelajaran lebih penting 
dibandingkan hasil dari pembelajaran itu sendiri, serta tidak ada seorang siswa pun yang dikritik/dihina dikarenakan rendahnya pengetahuan yang mereka miliki. Pembelajaran kooperatif lebih menekankan pada interaksi positif antara siswa serta suasana pembelajaran yang positif dan menyenangkan, yang bebas dari ketegangan, sehingga siswa tidak bosan dan merasa cemas ketika belajar matematika. Sejalan dengan pendapat yang dikemukakan oleh [13] bahwa pembelajaran kooperatif dapat memberikan kesempatan pada siswa untuk berinteraksi secara bebas dengan temannya dan berpartisipasi aktif dalam proses pembelajaran.

Berdasarkan pandangan Johnson dan Johnson's, pada pembelajaran kooperatif, siswa tidak merasa saling berkompetensi, sehingga menyebabkan berkurangnya kecemasan matematika [10]. Siswa menyelesaikan permasalahan yang terjadi selama pembelajaran melalui diskusi antarkelompok ataupun konsultasi dengan guru, sehingga siswa menyadari keberhasilan yang mereka capai dalam menyelesaikan persoalan tidak dapat dilakukan seorang diri tetapi memerlukan bantuan dari teman lainnya [10].

Sementara itu, pada pembelajaran konvensional, konsep diberikan dan dijelaskan oleh guru, kemudian contoh soal diberikan untuk melengkapi penjelasan materi, dilanjutkan pemberian tugas pada siswa dengan meminta salah seorang siswa untuk mengerjakan di depan kelas, dan pada akhir pembelajaran siswa diberi tugas pekerjaan rumah. Pada pembelajaran konvensional guru jarang memberikan kesempatan kepada siswa untuk menjawab pertanyaan yang diajukan oleh siswa lain, sehingga interaksi yang terjadi hanya antara guru-siswa atau siswa-guru saja. Selain itu, dalam pembelajaran konvensional, siswa dituntut untuk dapat menyelesaikan masalahnya seorang diri, karena siswa tidak diberikan kesempatan untuk bekerja sama dan berinteraksi dengan temannya [14].

Hasil pengamatan juga menunjukkan bahwa dalam pembelajaran konvensional, siswa terlihat lebih pasif jika dibandingkan dengan pembelajaran kooperatif, siswa kurang berusaha untuk menemukan sendiri penyelesaian masalah yang diberikan oleh guru. Jika guru memberikan tugas atau permasalahan yang menuntut kemampuan pemahaman matematis maka siswa terlihat mengalami kesulitan dalam menyelesaikannya. Hal ini dikarenakan mereka hanya terbiasa untuk memanipulasi simbol matematik dan mengerjakan masalah rutin matematis, tanpa memahami konsep matematis secara lebih mendalam. Selain itu, suasana belajar yang monoton juga dapat mengakibatkan siswa mudah bosan dan cemas. Akibatnya, kecemasan matematika siswa yang mendapatkan pembelajaran konvensional juga lebih tinggi daripada siswa yang mendapatkan pembelajaran kooperatif.

\section{SIMPULAN}

Karena $\left|Z_{\text {hitung }}\right|>\left|Z_{\text {kritis }}\right|, \quad$ yaitu 2,279 $>1,65$ atau nilai Sig. (1-tailed) pada uji Mann-Whitney, yaitu $0,023<\alpha$ sehingga $\mathrm{H}_{0}$ ditolak, yang berarti kecemasan matematika siswa yang memperoleh pembelajaran kooperatif lebih rendah daripada siswa yang mendapatkan pembelajaran konvensional.

\section{DAFTAR PUSTAKA}

[1] P. Poorya, A. Hassan, and R. Farzad. "A Predictive Model for Mathematical Performance of Blind and Seeing Students". International Research Journal, Educational Research, vol. 2, no. 2, pp. 864-873, 2011.

[2] F. Y. Sahin. "Mathematics Anxiety Among 4th and 5th Grade Turkish 
Elementary School Students". International Electronic Journal of Mathematics Education, vol. 3, no. 3, pp. 179-192, 2008.

[3] G. Gresham. "A Study Exploring Exceptional Education Pre-service Teachers' Mathematics Anxiety". IUMPST: The Journal, vol. 4, 2010.

[4] Nurhanurawati dan S. Sutiarso. "Mengatasi Kecemasan (Anxiety) dalam Pembelajaran Matematika. JPMIPA, vol. 9, no. 1, 2008.

[5] X. Luo, F. Wang, and Z. Luo. "Investigation and Analysis of Mathematics Anxiety in Middle School Students". Journal of Mathematics Education, vol. 2, no. 2, pp. 12-19, 2009.

[6] C. Blazer. "Strategies for Reducing Math Anxiety". Information Capsule Research Service, vol. 1102, 2011.

[7] S. Vahedi and F. Farrokhi. "A Confirmatory Factor Analysis of the Structure of Abbreviated Math Anxiety Scale". Iran Journal Psychiatry, vol. 6, pp. 47-53, 2011.

[8] S. Daneshamooz, H. Alamolhodaei, and S. Darvishian. "Experimental Research About Effect of Mathematics Anxiety, Working Memory Capacity on Students' Mathematical Performance with Three Different Types of Learning Methods". ARPN Journal of Science and Technology, vol. 2, no. 4, 2012.

[9] E. Zakaria and N. M. Nordin. "The Effects of Mathematics Anxiety on Matriculation Students as Related to Motivation and Achievement". Eurasia Journal of Mathematics, Science \& Technology Education, vol. 4, no. 1, pp. 27-30. 2008.

[10] M. G. Lavasani and F. Khandan. "The Effect of Cooperative Learning on Mathematics Anxiety and Help Seeking Behavior". Science Direct, Procedia Social and Behavioral Sciences, vol. 15, pp. 271-276, 2011.
[11] D. Anggraeni. "Meningkatkan Kemampuan Pemahaman dan Komunikasi Matematika Siswa SMK melalui Pendekatan Kontekstual dan Strategi Formulate-Share-ListenCreate", 2012. [Online]. Tersedia: http://repository.upi.edu/operator/upl oad/t_mat_1007350_chapter2.pdf.

[12] A. Cooke, R. Cavanagh, C. Hurst, and L. Sparrow. "Situational Effects of Mathematics Anxiety in PreService Teacher Education". AARE Conference Proceedings, 2011.

[13] K. Witherell. "Communication of Mathematics Within Cooperative Learning Groups". Math in the Middle Institute Partnership, Action Research Project Report, 2010. [Online]. Tersedia: http://scimath.unl.edu/MIM/files/rese arch/Witherell_AR_Final_LA.pdf.

[14] M. Batton. "The effect of cooperative groups on math anxiety". Disertasi. Walden University, 2010. [Online]. Tersedia:

http://scholarworks.waldenu.edu/cgi/ viewcontent.cgi? article $=1821 \&$ conte $\mathrm{xt}=$ dissertations 